\title{
Multiple Criteria and Multiple Periods Performance Analysis: A Comparison of North African Railways
}

\author{
A. Mapapa Mbangala \\ Kinshasa Higher Institute of Commerce (ISC-Kinshasa) \\ Karim Sabri \\ Casablanca Ain Sebaa University \\ Gérard E. Colson \\ University of Liege
}

\begin{abstract}
Multi-period differences of technical and financial performances are analyzed by comparing five North African railways over the period 1990-2004. A first approach is based on the Malmquist DEA TFP index for measuring the total factors productivity change, decomposed into technical efficiency change and technological changes. A multiple criteria analysis is also performed using the PROMETHEE II method and ARGOS software. These methods provide complementary detailed information, especially by discriminating the technological and management processes by Malmquist and the two dimensions of performance by Promethee, service to the community and enterprise performance, which are often in conflict.
\end{abstract}

Keywords: case study, multiple criteria decision aid, Promethee, Malmquist dea tfp index, North African Railways, multiple periods performance analysis

\section{INTRODUCTION}

Conceived as a vector for strategic economic development, the African railway companies have become a source of exasperation in the economic and financial crises that shake some African States. The analysis of the terrestrial transport policy in most African countries emphasizes an absence of planning such that the configuration of transport infrastructure in Africa produces serious problems for economic and social development coordination and in means of transport as well. Thus, the evaluation and measurement of public utilities presented by Estache and Kouassi, especially in developing countries, became a crucial point in the open and liberal economies. Yet, there is a surprising lack of literature that measures the efficiency of operators in a way that would allow economic regulators to introduce explicit performance incentives in the regulation of operators in African countries.

The total productivity of factors is well known in the economic literature and was the subject of several empirical evaluations, particularly on public services in networks (Coelli and Perelman) (Plane). The analysis of productivity contributes a sound base of information and thinking on the way in which 
organizations are managed. From this point of view, this paper aims to measure the performance of North African railways. Within the framework of liberalization and privatization, this measurement can help the regulator understand what is needed in order to improve at the level of network performance (Estache et al.).

The first approach compares network productivity based on the Malmquist index (Estache et al.). Next, we use multiple criteria analysis in order to compare the quoted railway networks according to two general dimensions of performance (technical and economic), aggregating several families of criteria. In this respect, we will use the multiple criteria ranking provided by the method Promethee II (Brans et al.) and included in the ARGOS software (Colson).

\section{BACKGROUND OF THE NORTH AFRICAN RAILWAYS}

\section{In Algeria}

The Northern African Railways rail network is managed by the National Company of Railroad Transport (Société Nationale des Transports Ferroviaires: SNTF). It consists of 3,973 km of lines of which $2,888 \mathrm{~km}$ present a normal gauge $(1435 \mathrm{~mm})$ and $1,085 \mathrm{~km}$ a narrow spacing $(1055 \mathrm{~mm})$. This network is the third longest in Africa after the South African and Egyptian networks. However, it remains insufficient for Algeria's economic needs. Mainly inherited from colonial times, it comprises lines of both normal and narrow gauge. The mining line that connects the mines of Ouenza to the town of Annaba $(300 \mathrm{~km})$ is the only electrified line. The network comprises $400 \mathrm{~km}$ of double tracks mainly in the north of the country. The network structure follows the development and location of the population, industry, and mining sources. The crossing ways in the stations are short and do not allow long trains, and the signal and communication systems are decayed and do not allow modernization. Algeria intends to open access to the railroad transport system to the private sector under a mode of concession. It is envisaged to stop the monopoly of the SNTF on rail, which is the only transport sector still avoiding competition since road transport was opened to the private sector in 1988 and maritime and air transport in 1998. The general trend of privatization in North Africa provides an opportunity to delegate the exploitation of the national rail network to one or more companies under the concession mode. The opening of railroad transport to competition is justified by the fact that the monopoly of the State involved a constant reduction in the performance of this means of transport and systematic recourse to the Treasury for its financing. The private sector should carry the load of rehabilitation and development of the rail network.

\section{In Libya}

The railway mode is not yet existent in Libya because road transport ensures the totality of the carriage of goods and passengers. Two national companies operate in the sector: one for long-distance transport and the other committed to inter-city connections. Transport by taxi is also used for short and average distances.

\section{In Morocco}

Railroads in Morocco are managed by the National Office of the Railroads (Office National des Chemins de Fer ONCF), a publicly owned establishment with financial autonomy. ONCF exploits 1,907 $\mathrm{km}$ of national network of which 1,003 km are electrified and $370 \mathrm{~km}$ have a double track. This network is composed of a principal line connecting Marrakech to the south to Oujda on the Morocco-Algeria border, with ramifications toward Tangier in the north, phosphate mining zones, and some large ports. Since the end of the $1980 \mathrm{~s}$, the ONCF has undertaken a comprehensive program of modernization of the network related to the reorganization of some stations, the renewal of ways, and the installation of telecommunications and signals in order to offer a quality service to its customers.

\section{In Mauritania}

In order to transport iron from its place of extraction to its place of transformation and export, the Mauritanian State financed the construction of a $670 \mathrm{~km}$ railway line with a single track between the iron fields of Fderik and the port of Nouadhibou. Six convoys of 220 coaches (2000 tons per convoy) have 
traversed this since its opening in 1963. It is the longest train in the world at more than $2 \mathrm{~km}$ in length. The train crosses an almost uninhabited zone and transports only ore. Maintenance services exist all along the railroad. The equipment is maintained perfectly as the iron trade is unacceptable to stop the trade of iron as it is the country's primary source of income. This network is owned and operated by the Mauritanian public Enterprise SNIM (Société Nationale Industrielle Minière). The train also accommodates several coaches intended for passenger transport.

Due to the lack of reliable available data, an analysis of the Mauritanian network is not included in this study.

\section{In Tunisia}

The overall length of the network is 2,196 km of which nearly $1,862 \mathrm{~km}$ are currently in use. The network presents a majority of metric gauge $(1,687 \mathrm{~km})$, except for the Tunis-Ghardimaou (trans-Maghreb) line at $471 \mathrm{~km}$ length whose branches $(116 \mathrm{~km})$ present normal gauge. Owing to the fact that the majority of the lines converge toward Tunis, this difference in gauge does not seem to constitute, for the moment, a major handicap. However, if the Maghrebian network were to develop (toward Libya), then the difference in gauge could constitute a serious problem. The structure of the network is conceived to ensure a good service road. In addition, the agricultural zones in the country's northeast and center, and all the frontier mining zones are connected to the large clusters of activity and ports located on the littoral zone.

The railway activity is managed by two public operators: The publicly owned National Company of the Tunisian Railroads (Société Nationale des Chemins de Fer Tunisiens: SNCFT) and the Company of the Leger Subway of Tunis (Société du Métro Léger de Tunis: SMLT), which operates the large urban subway system in Tunis. This $135 \mathrm{~km}$ of railway line presents double tracks and only $65 \mathrm{~km}$ are electrified.

\section{In Egypt}

The first railway built in Africa was in Egypt in 1853. The idea of building a railway dates back to 1833, when Mohamed Ali consulted his Scottish chief engineer, T. Gallway, about building a road between Suez and Ain Shames to become the link between Europe and India. Mohamed Ali initiated the project and bought the rails in order to start building the road and the stations. However, France was able to prevent this from happening because the French government wanted to substitute this project with building a canal between the Red and the Mediterranean Seas. Mohamed Ali found himself shattered between the two ideas, so he refused to carry out any of them. When Mohamed Ali died in 1849, England wrote to his successor, Abass Helmy I, asking him to build a railway in Egypt. He agreed and signed a contract with Robert Stephenson on the 12th of June 1851. The contract asserted that the work should start in September of the same year and that Stephenson should be responsible for all matters of the project. The first railway route in Egypt was built in 1854 between Alexandria and Kafer Eassa, and it reached Cairo in 1856. In 1858, the route between Cairo and Suez was built, but was removed in 1878 after digging the Suez Canal. A new route was built in 1867 to connect Cairo with southern Egypt and Imbaba Bridge was built in 1891 to enable the trains to pass over the Nile near Cairo. From this point on, the railway has become one of the most important means of transportation in Egypt. You can use the railway to go as far as Matrouh (Libya frontier) in the west and as far as Aswan in the north. Passengers can depend on the railway service to travel all over Egypt. The railway activity is operated by public enterprise Egyptian National Railways (ENR) with 4974 mean line kilometers.

\section{A COMPARISON OF PRODUCTIVITIES OF THE RAILWAYS' NETWORKS BASED ON THE MALMQUIST INDEX}

Table 1 presents differences in the sizes of the railways as expressed in line kilometers. According to these figures, Egypt has the largest with 4,974 line km followed by Algeria $(4,124)$, Tunisia $(2,133)$, and Morocco $(1,905)$. We can explain this difference by the area of each country and by the goals of colonization. We shall see that the ranking by productivity does not reflect the size ranking of networks. 
TABLE 1

SIZE OF RAILWAYS EXPRESSED IN LINE KILOMETERS (*)

\begin{tabular}{lllll}
\hline & $\begin{array}{l}\text { ALGERIA } \\
\text { SNTF }\end{array}$ & $\begin{array}{l}\text { EGYPT } \\
\text { ENR }\end{array}$ & $\begin{array}{l}\text { MOROCCO } \\
\text { ONCF }\end{array}$ & $\begin{array}{l}\text { TUNISIA } \\
\text { SNCFT }\end{array}$ \\
\hline Mean Line Km & 4124 & 4974 & 1905 & 2133 \\
\hline Ranks & 2nd & 1st & 4 th & $3^{\text {rd }}$ \\
\hline
\end{tabular}

* Source: UIC (Union internationale des chemins de fer)

\section{Methodology of the Malmquist Index Analysis}

We begin our analysis by having recourse to the Malmquist index (Färe et al.). One can read a description of this index in "A Primer on Efficiency Measurement for Utilities and Transport Regulators" (Coelli et al.):

"The Malmquist index of productivity measures the variation of productivity (TFP) between two observations, by calculating the ratio of the distances from each data (network) compared to a common technology (the efficient frontier of production). The Malmquist index of variation of TFP (directed in input) between period 0 (the basic period) and period 1 (by using the technology of period 1 as technology of reference) is defined by:

$\mathrm{TFP}_{1} / \mathrm{TFP}_{0}=\mathrm{D}_{1}\left(\mathrm{Y}_{0}, \mathrm{X}_{0}\right) / \mathrm{D}_{1}\left(\mathrm{Y}_{1}, \mathrm{X}_{1}\right)$

where the notation $\mathrm{Dt}(X s, Y s)$ represents the distance between the observation of the period $S$ and the technology of the period T, and XS and YS are, respectively, the input and the output in period $S$.

A value of this ratio in (1) higher than 1 will mean an improvement of the TFP.",

Our study relies on the physical data of four North African railway networks (Algeria, Egypt, Morocco, and Tunisia) over a 15 year period (1990-2004). This method allows us to know the origins of the positive or negative evolutions of the total productivity of the operators differentiated into technological change and change of efficiency: the latter often reflects management improvements within each network while the former reflects innovation (e.g., new investments). In this same quoted reference and using Färe et al. [10]), we read that the Malmquist productivity index is defined as the geometric mean of two indices, namely, an index evaluated in connection with technology of period 1 and another in connection with the technology of period 0 . We obtain then:

$\mathrm{TFP}_{1} / \mathrm{TFP}_{0}=\left[\mathrm{D}_{1}\left(\mathrm{Y}_{0}, \mathrm{X}_{0}\right) / \mathrm{D}_{1}\left(\mathrm{Y}_{1}, \mathrm{X}_{1}\right) * \mathrm{D}_{0}\left(\mathrm{Y}_{0}, \mathrm{X}_{0}\right) / \mathrm{D}_{0}\left(\mathrm{Y}_{1}, \mathrm{X}_{1}\right)\right]^{0.5}$

We can also transform (2) in (3):

$\mathrm{TFP}_{1} / \mathrm{TFP}_{0}=\mathrm{D}_{0}\left(\mathrm{Y}_{0}, \mathrm{X}_{0}\right) / \mathrm{D}_{1}\left(\mathrm{Y}_{1}, \mathrm{X}_{1}\right)\left[\mathrm{D}_{1}\left(\mathrm{Y}_{0}, \mathrm{X}_{0}\right) / \mathrm{D}_{0}\left(\mathrm{Y}_{0}, \mathrm{X}_{0}\right) * \mathrm{D}_{1}\left(\mathrm{Y}_{1}, \mathrm{X}_{1}\right) / \mathrm{D}_{0}\left(\mathrm{Y}_{1}, \mathrm{X}_{1}\right)\right]^{0.5}$

The ratio outside the brackets of (3) measures the change in the input-oriented measure of technical efficiency between periods 0 and 1 . The remaining part of the index in the equation is a measure of technical change, i.e., the geometric mean of the technical change between the two periods, evaluated with the observations of periods 0 and 1 . 


\section{Presentation of Data and Choice of Variables}

Table 2 gathers all the data available for the analysis concerning the railways operators in the four North African countries during 1990-2004.

As output, we chose "passenger-kilometers" (P-km) and «ton-kilometers» (T-km) (A. M. Mbangala). We could have chosen, for example, the sales turnover that reflects the sold production of the operators. However, several problems remain regarding the availability of reliable data and the diversity of the countable standards in each country encouraged us to avoid this kind of output.

Equipment (total number of coaches and wagons) and railway employees are the input variables. We notice the absence of Sudan and Mauritania in this presentation due to a lack of data reliability.

TABLE 2

INPUTS AND OUTPUTS (*) OF THE MALMQUIST DEA TFP INDEX ANALYSIS

\begin{tabular}{|c|c|c|c|c|c|}
\hline \multirow[b]{2}{*}{ Railways } & \multicolumn{2}{|c|}{ Outputs } & \multicolumn{2}{|c|}{ Inputs } & \multirow[b]{2}{*}{ Manpower } \\
\hline & Year & T-km & P-km & Equipment & \\
\hline \multirow{15}{*}{ Algeria } & 1990 & 2178000 & 2990851 & 10650 & 18200 \\
\hline & 1991 & 2716736 & 3192091 & 10930 & 18104 \\
\hline & 1992 & 2529701 & 2903505 & 6893 & 18187 \\
\hline & 1993 & 2304584 & 3009728 & 10653 & 17497 \\
\hline & 1994 & 2278800 & 2234011 & 10894 & 16780 \\
\hline & 1995 & 2121000 & 1797000 & 10950 & 16600 \\
\hline & 1996 & 2301430 & 1826113 & 10911 & 16269 \\
\hline & 1997 & 2301430 & 1826113 & 10845 & 16269 \\
\hline & 1998 & 2174000 & 1163000 & 10806 & 14400 \\
\hline & 1999 & 2033000 & 1163251 & 10796 & 14385 \\
\hline & 2000 & 1979714 & 1141646 & 10573 & 12510 \\
\hline & 2001 & 1990000 & 981000 & 10558 & 12300 \\
\hline & 2002 & 2247000 & 955000 & 10488 & 11400 \\
\hline & 2003 & 2040892 & 963517 & 10483 & 11420 \\
\hline & 2004 & 1947135 & 949872 & 10466 & 11139 \\
\hline \multirow[t]{15}{*}{ Morocco } & 1990 & 5107346 & 2237276 & 10477 & 13716 \\
\hline & 1991 & 4526170 & 2345462 & 9022 & 14002 \\
\hline & 1992 & 5001100 & 2232718 & 9079 & 14157 \\
\hline & 1993 & 4419089 & 1903566 & 8897 & 14349 \\
\hline & 1994 & 4679216 & 1881191 & 8623 & 14385 \\
\hline & 1995 & 4621201 & 1530892 & 8443 & 13782 \\
\hline & 1996 & 4757208 & 1686398 & 7561 & 12639 \\
\hline & 1997 & 4834688 & 1855934 & 7265 & 12016 \\
\hline & 1998 & 4757000 & 1875000 & 7121 & 11600 \\
\hline & 1999 & 4794499 & 1880000 & 7016 & 10905 \\
\hline & 2000 & 4576000 & 1956000 & 6700 & 10308 \\
\hline & 2001 & 4622000 & 2019000 & 6417 & 10200 \\
\hline & 2002 & 4974000 & 2145000 & 6421 & 9800 \\
\hline & 2003 & 5146525 & 2374169 & 6282 & 9487 \\
\hline & 2004 & 5563323 & 2644583 & 6037 & 9207 \\
\hline
\end{tabular}




\begin{tabular}{|c|c|c|c|c|c|}
\hline \multirow[t]{15}{*}{ Egypt } & 1990 & 3028979 & 38533000 & 17054 & 88000 \\
\hline & 1991 & 3276000 & 41151000 & 16717 & 88000 \\
\hline & 1992 & 3211511 & 42589000 & 15906 & 88000 \\
\hline & 1993 & 3141129 & 46338000 & 14143 & 71653 \\
\hline & 1994 & 3621000 & 44293000 & 14437 & 72890 \\
\hline & 1995 & 4072577 & 48242000 & 14800 & 74123 \\
\hline & 1996 & 4117000 & 50465000 & 14947 & 74015 \\
\hline & 1997 & 3969000 & 52926000 & 16276 & 71684 \\
\hline & 1998 & 4265000 & 55000000 & 16200 & 71062 \\
\hline & 1999 & 3464000 & 59638000 & 16242 & 71000 \\
\hline & 2000 & 4000000 & 63060000 & 16123 & 70900 \\
\hline & 2001 & 4217000 & 66008000 & 15889 & 70750 \\
\hline & 2002 & 4188000 & 39083000 & 14661 & 70500 \\
\hline & 2003 & 4104000 & 46185000 & 15028 & 70200 \\
\hline & 2004 & 4321000 & 52682000 & 15101 & 70000 \\
\hline
\end{tabular}

* Sources: Algeria: Société Nationale des Transports Ferroviaires (SNTF); Morocco: Office National des Chemins de fer (ONCF); Egypt: Egyptian National Railways (ENR); Tunisia: Société Nationale des Chemins de Fer Tunisiens (SNCFT); UIC: l'Union internationale des chemins de fer

\section{Presentation and Analysis of the Results}

From Table 3, "MALMQUIST INDEX SUMMARY OF ANNUAL MEANS," we conclude that the total growth annual rate is 3.2\% over the period 1990-2004. We have converted the indices to growth rates. The decomposition of this rate shows that this growth comes primarily from the column "technological progress," which reflects the development of the investment level in the railways sector. This change is mainly due to the investment in equipment. Technological progress takes part at a rate of $4.4 \%$ in the growth. The remaining effect is negative $(1.2 \%)$ issued from the column "change of the technical efficiency" that assesses the evolution of the management in this sector. We can therefore conclude that North African railways are very inefficient much like a majority of state-owned enterprises (SOEs) in developing countries.

TABLE 3

MEAN PRODUCTIVITY CHANGES OF THE NORTH AFRICAN RAILWAYS 1990-2004

MALMQUIST INDEX SUMMARY OF ANNUAL MEANS (converted to growths rates) $\underline{\underline{1}}$

\begin{tabular}{cccc}
\hline Year & Efficiency change & Technological change & $\begin{array}{c}\text { Total factors productivity } \\
\text { change }\end{array}$ \\
\hline $1991 / 1990$ & $+3.3 \%$ & $+1.1 \%$ & $+4.4 \%$ \\
1992 & $+2.3 \%$ & $+6.9 \%$ & $+9.4 \%$ \\
1993 & $-2.6 \%$ & $-1.2 \%$ & $-3.7 \%$ \\
1994 & $-0.2 \%$ & $+2.5 \%$ & $+2.3 \%$ \\
1995 & $-2.9 \%$ & $+2.5 \%$ & $-0.4 \%$ \\
1996 & $-3.4 \%$ & $+10.3 \%$ & $+6.6 \%$ \\
1997 & $-2.8 \%$ & $+6 \%$ & $+3.1 \%$ \\
1998 & $-2.3 \%$ & $+2.9 \%$ & $+0.6 \%$ \\
1999 & $-5.9 \%$ & $+5.5 \%$ & $-0.8 \%$ \\
2000 & $+5.8 \%$ & $+3.7 \%$ & $+9.7 \%$ \\
2001 & $+3.2 \%$ & $+3.7 \%$ & $+7.0 \%$ \\
2002 & $+1.5 \%$ & $-3.0 \%$ & $-1.5 \%$ \\
2003 & $-6.3 \%$ & $+9.9 \%$ & $+3.0 \%$ \\
$2004 / 2003$ & $-6.0 \%$ & $+12.5 \%$ & $+5.7 \%$ \\
\hline Mean & $\mathbf{- 1 . 2 \%}$ & $+\mathbf{4 . 4 \%}$ & $+\mathbf{3 . 2 \%}$ \\
\hline
\end{tabular}


TABLE 4

PRODUCTIVITY CHANGES OF THE NORTH AFRICA RAILWAYS 1990-2004 BY COUNTRY

\begin{tabular}{llcc}
\multicolumn{4}{c}{ MALMQUIST INDEX SUMMARY OF NETWORKS MEANS (converted in growths rates) } \\
\hline Sector & Efficiency change & Technological change & Total factors productivity change \\
\hline Algeria & $-4.6 \%$ & $+4.9 \%$ & $+0.1 \%$ \\
Egypt & $0.0 \%$ & $+3.8 \%$ & $+3.8 \%$ \\
Morocco & $0.0 \%$ & $+4.1 \%$ & $+4.1 \%$ \\
Tunisia & $-0.3 \%$ & $+5.0 \%$ & $+4.7 \%$ \\
\hline Mean & $\mathbf{- 1 . 2 \%}$ & $+\mathbf{4 . 4 \%}$ & $+\mathbf{3 . 2} \%$ \\
\hline
\end{tabular}

* Note that all Malmquist index averages are geometric means

The second table, "MALMQUIST INDEX SUMMARY OF NETWORK MEANS," indicates for each year the networks that contributed more (or less) than others to the improvement of productivity. We can confirm that Tunisia comes at the head of the ranking with a rate of $4.7 \%$ to the total growth rate followed by Morocco (4.1\%), Egypt (3.8\%), and Algeria (0.1\%). We can notice for all operators that the rates of the technological column are higher than those of the effectiveness column, confirming that the annual total growth rate results mainly from the technical progress and reflecting investment in the railway sector. The average efficiency change is negative due probably to weakness in management.

According to the average growth in productivity (Table 4), we can rank the countries' railway performance as follows:

Tunisia: 1st (+4.7\%); Morocco: 2nd (+4.1\%); Egypt: 3rd (+3.8\%); Algeria: 4th (0.1\%)

We can also compare this ranking to the first ranking made by size (Table 1). Network size cannot give a good evaluation of companies' productivity (Table 5).

TABLE 5

COMPARED RANKINGS OF THE NORTH AFRICA RAILWAYS FROM 1990 TO 2004 BY SIZE AND PRODUCTIVITY (MALMQUIST INDEX)

\begin{tabular}{cllll}
\hline Ranks & $1^{\text {st }}$ & $2^{\text {nd }}$ & $3^{\text {rd }}$ & $4^{\text {th }}$ \\
\hline Size ranking & Egypt & Algeria & Tunisia & Morocco \\
\hline Malmquist index ranking & Tunisia & Morocco & Egypt & Algeria \\
\hline
\end{tabular}

\section{A COMPARISON OF PERFORMANCES OF THE RAILWAYS NETWORKS WITH PROMETHEE II}

\section{Data and Ratios Presentation}

Data concerning the railway operators in the four North African countries during the period 1990-2004 are gathered in Table 6 hereafter while in Table 7 we compute ratios free of the rates of money changes and inflation.

\section{Recalling the Promethee II Method ${ }^{2}$}

Multiple criteria methods are well known in the literature. One of the best-known methods is the second release of Promethee by Brans et al. The Promethee II method is an outranking multiple criteria device that provides a preorder of items by making pair wise comparisons of these items (railway sectors = networks, in our case) first for each criterion and then for all criteria. The final ranking is obtained according to the decreasing order of the preference flows of the items. Among the six kinds proposed by the method, we used only one kind of criterion: the pseudo-criterion with a linear preference between the two thresholds (Fig. 1).

The linear pseudo-criterion used in Promethee is as follows: 


\section{FIGURE 1 \\ PSEUDO-CRITERION WITH A LINEAR PREFERENCE BETWEEN THE TWO THRESHOLDS}

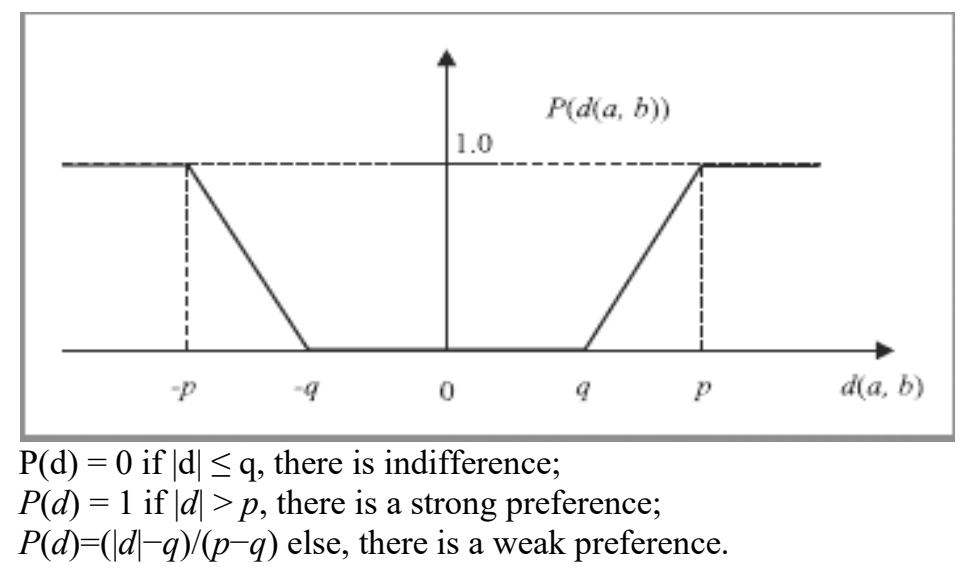

Let $\mathrm{a}$ and $\mathrm{b}$ stand for two items and let $d(a, b)$ be the difference of their evaluations on a criterion $c$. We assume that a positive $d(a, b)$ corresponds to a preference for $a$ over $b$. The preference function $P(d(a, b))$ is assumed to take the value 1 as soon as the preference is strong (= clearly stated), i.e., when $|d|>p$, the preference threshold, and is assumed to take the value 0 when an indifference between $a$ and $b$ is decided because their evaluation difference does not reach the threshold q. Between these two decisions, a weak preference is expressed and $P$ linearly increases with $d$. Thus, this criterion states that $a$ is surely preferred to $b$ when $P(d(a, b))=1$. For the sake of simplicity, let us write $P c(a, b) \equiv P c(d(a, b))$ : the preference function for the criterion $\mathrm{c}$.

The method defines then a multi-criteria preference index as the weighted average of the preference functions Pc for all criteria. In our application, we considered that the three criteria of each point of view had the same weights. The index Phi(a,b) is computed by the next equation:

$\operatorname{Phi}(a, b)=[P 1(a, b)+P 2(a, b)+P 3(a, b)] / 3$.

This index is called the (multi-criteria) preference flow of a over $b$. We are more confident that a is preferred to $b$ according to all criteria of the considered family when the flow value is closer to 1 . Of course, $a$ is surely preferred to $b$ when the unanimity of criteria is in favor of $a$ and then Phi(a,b) $=1$. At this stage, Promethee proposes plotting a graph on the set $\mathrm{K}$ of considered items with its nodes being all of the compared items: $a, b, c, \ldots$ of $K$. The arcs joining two items are valued by Phi $(a, b)$ and Phi $(b, a)$ for a pair $(a, b)$. Then, the method computes two flows for an item a:

$\operatorname{Phi}^{+}(a)=\sum_{b \in K} \operatorname{Phi}(a, b)$ : the leaving flow $\operatorname{Phi}{ }^{-}(a)=\sum_{b \in K} \operatorname{Phi}(b, a)$ : the entering flow.

One interprets the leaving flow as a multi-criteria force of preference of a on the other items in $\mathrm{K}$, and the entering flow as a multi-criteria preference weakness of a.

In Promethee II, a balance of flows is completed, delivering a net preference flow for each item a on all the other items and for all criteria of the family:

$\operatorname{Phi}(a)=[P h i+(a)]-[P h i-(a)]:$ the net flow in favor of $a$.

Usually, by ranking the net flows in decreasing order, we obtain the preference ranking of the items: positive flows associated with the dominating items and negative ones associated with dominated ones. Note that unlike the classical method Promethee, we did not divide the flows by $(n-1)$ with $n$ being the number of 
items in Eq. (5); our simplification was done in order to point out the maximum number of possible dominances.

\section{Methodology of the Multi-Criteria Analysis at Three Levels}

To analyze the performance of the railways sector (networks) in the four North African countries by a multi-criteria method, we based our analysis on two dimensions of performance of public companies: effectiveness of public service and efficiency of those in terms of using resources. We borrow this methodology from Colson and Mbangala.

These authors constituted a hierarchy at three levels of selected criteria. Here, we have initially incorporated three or four basic criteria to constitute a coherent family. The four families are then gathered into two dimensions of analysis (also called "assessment functions"). Table 6 presents this hierarchy and the preference, and the indifference thresholds of the adopted 14 pseudo-criteria. According to the first dimension, described as technical, we aim to collect performance data of the sector from the users' point of view. This first dimension is a general performance function that measures the importance of (public) service to the user and to the country by the railway sector (four criteria per family). The second dimension evaluates the economic health of the sector (three criteria per family) by means of two families: railways economic performance and the firm's global performance.

We adopted only one type of criterion: the linear pseudo-criterion (with two thresholds of decision) because this type fits well with less reliable data than usual and avoids a strong preference for a small variance. The first threshold $(q)$ is the limit between a decision of indifference between two actions (networks) and a decision of weak preference.

For the calculation of multi-criterion preference flows of all sectors, we used ARGOS software (Colson), which has the advantage of being able to treat directly two levels of hierarchy of criteria. Recall, however, that the multi-criteria flows are not reduced in an interval $[0,1]$ in this software as it was in the original Promethee method. Table 6 synthesizes the criteria and the families with their thresholds. The second column indicates the thresholds $\mathrm{q}$ that mark the end of an indifference between two operators due to the weakness of the differences in evaluation between these two operators on a same criterion; a third column indicates the thresholds $p$ and a last column shows the preferable direction ( $\max$ or min) for each criterion.

TABLE 6

VENTILATION OF THE CRITERIA ACCORDING TO THE FAMILIES AND DIMENSIONS WITH THE THRESHOLDS AND THE CRITERION DIRECTION

FUNCTIONS, FAMILIES AND CRITERIA PER FAMILY

\begin{tabular}{|c|c|c|c|}
\hline & $\frac{\text { Threshold }}{\underline{q}}$ & $\frac{\text { Threshold }}{\mathrm{p}}$ & $\underline{\text { Criterion }}$ \\
\hline \multicolumn{4}{|c|}{$\begin{array}{l}\text { 1- Technical assessment function } \\
\text { Freight traffic }\end{array}$} \\
\hline TKm/Traffic Units: Freight traffic part in TU & 1.5 & 4 & Max \\
\hline TKm/cars: Freight cars employment & 20 & 50 & Max \\
\hline TKm/Total Freight: Mean haulage length & 1.5 & 4 & Max \\
\hline $\begin{aligned} T K m / \text { Lines Km: } & \text { Freight traffic density } \\
& \text { Passenger traffic }\end{aligned}$ & 15 & 35 & Max \\
\hline PKm/Traffic Units: Passenger traffic part in TU & 1.5 & 4 & Max \\
\hline PKm/Cars: Passenger Cars employment & 100 & 250 & Max \\
\hline PKm/Passengers: Mean journey length & 0.5 & 1.5 & Max \\
\hline PKm/Lines Km: Passenger traffic density & 50 & 150 & Max \\
\hline
\end{tabular}




\begin{tabular}{lccc}
\hline \multicolumn{1}{c}{ 2- Economics assessment function } & & & \\
Railways Economics performance & & & Max \\
Traffic Units/GDP: Rail economic intensity & 50 & 150 & Max \\
PKm/Inhabitants: population-oriented service & 50 & 150 & Max \\
Lines Km/Area: Network geographical density & 0.1 & 0.3 & \\
$\quad$ Firm's Global performance & & & Max \\
Traffic Units/locos: Locos employment & 20 & 50 & Max \\
Traffic Units/Manpower: Manpower productivity & 10 & 25 & Max \\
Traffic Units/Lines: Network Density & 70 & 170 & \\
\hline
\end{tabular}




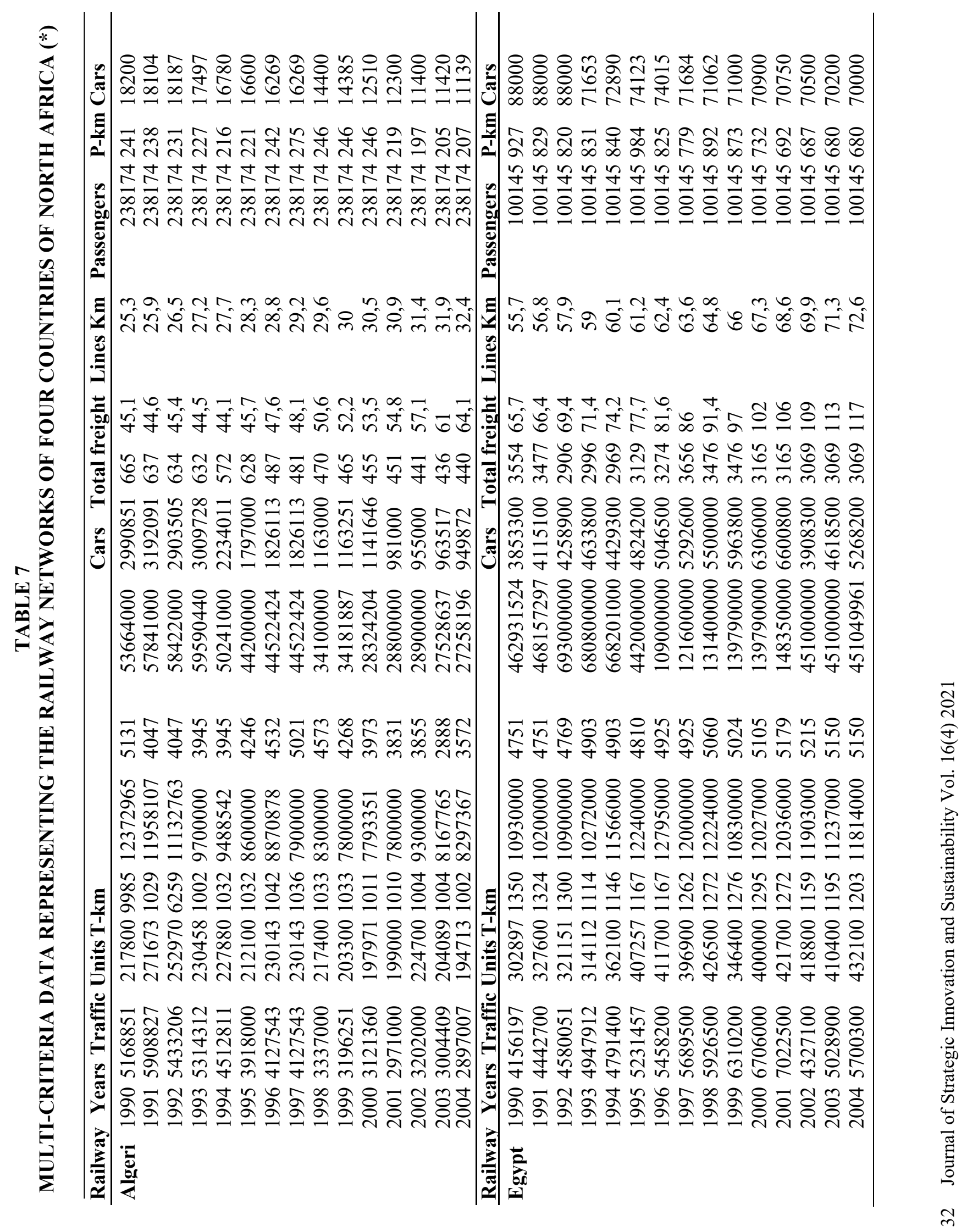




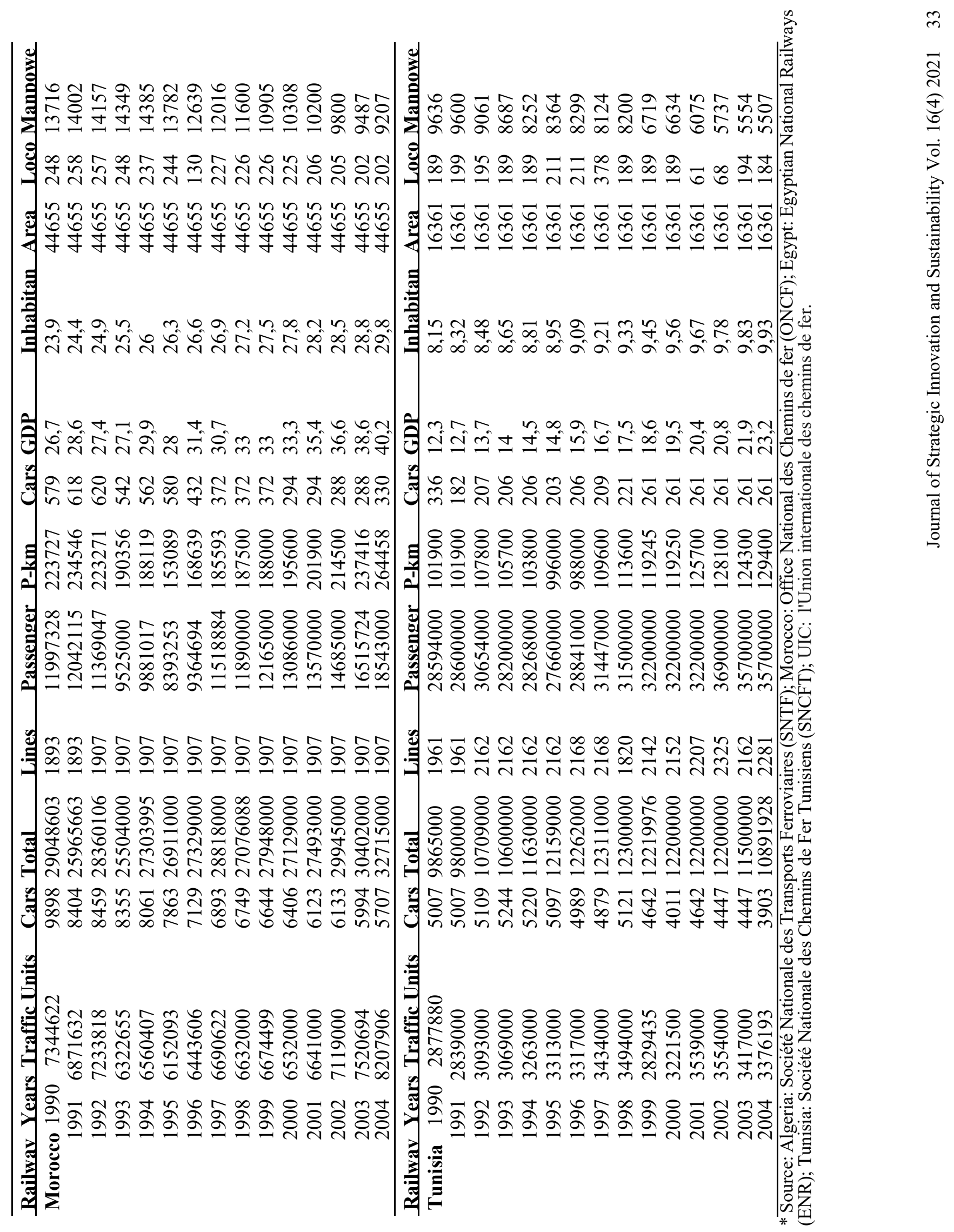


TABLE 8A

PROMETHEE II PREFERENCE FLOWS OF GENERAL PERFORMANCE FUNCTIONS FOR RAILWAYS IN FOUR NORTH AFRICAN COUNTRIES (*)

\begin{tabular}{|c|c|c|c|c|c|c|c|c|c|}
\hline & \multicolumn{2}{|c|}{ Algeria } & \multicolumn{2}{|c|}{ Egypt } & \multicolumn{2}{|c|}{ Morocco } & \multicolumn{2}{|c|}{ Tunisia } & \multirow[b]{2}{*}{ 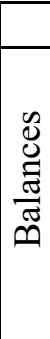 } \\
\hline & 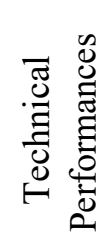 & 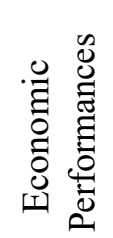 & 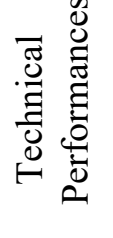 & 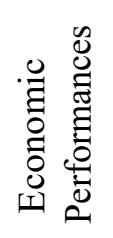 & 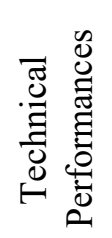 & 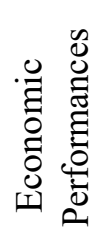 & 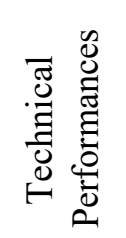 & 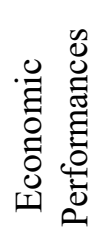 & \\
\hline 1990 & -19.7 & -31 & 17.5 & 35 & 17.5 & 5 & -15.3 & -9 & 0 \\
\hline 1991 & -15.4 & -22.5 & 15.4 & 38 & 12 & -0.5 & -12 & -15 & 0 \\
\hline 1992 & -11.6 & -30.5 & 14 & 37.5 & 12.4 & 0 & -14.8 & -7 & 0 \\
\hline 1993 & -20.5 & -29.2 & 20 & 40 & 12 & -2.7 & -11.5 & -8.1 & 0 \\
\hline 1994 & -23.4 & -38.8 & 20 & 40 & 11.9 & -1 & -8.5 & -0.2 & 0 \\
\hline 1995 & -25.6 & -40 & 16.8 & 40 & 15.8 & 0 & -7 & 0 & 0 \\
\hline 1996 & -25.6 & -40 & 16.8 & 40 & 15.8 & 0 & -7 & 0 & 0 \\
\hline 1997 & -29.5 & -37.5 & 16 & 40 & 17 & 2.2 & -3.5 & -4.7 & 0 \\
\hline 1998 & -30.4 & -44.9 & 16 & 40 & 19.5 & 2.5 & -5.1 & 2.4 & 0 \\
\hline 1999 & -31 & -42.5 & 16 & 40 & 25 & 5 & -10 & -2.5 & 0 \\
\hline 2000 & -30 & -43 & 16 & 40 & 22.5 & 4.5 & -8.5 & -1.5 & 0 \\
\hline 2001 & -31 & -45 & 16.5 & 40 & 22.4 & -0.2 & -7.9 & 5.2 & 0 \\
\hline 2002 & -32.5 & -45 & 20 & 32.5 & 22 & 5 & -9.5 & 7.5 & 0 \\
\hline 2003 & -32.5 & -38.5 & 20 & 35 & 22 & 0 & -9.5 & 3.5 & 0 \\
\hline 2004 & -32.5 & -44.5 & 20 & 35 & 21.5 & 10 & -9 & -0.5 & 0 \\
\hline Total & -391.2 & -572.9 & 261 & 573 & 269.3 & 29.8 & -139.1 & -29.9 & $\mathbf{0}$ \\
\hline
\end{tabular}

* Source: Calculation by Karim SABRI from ARGOS software results. 


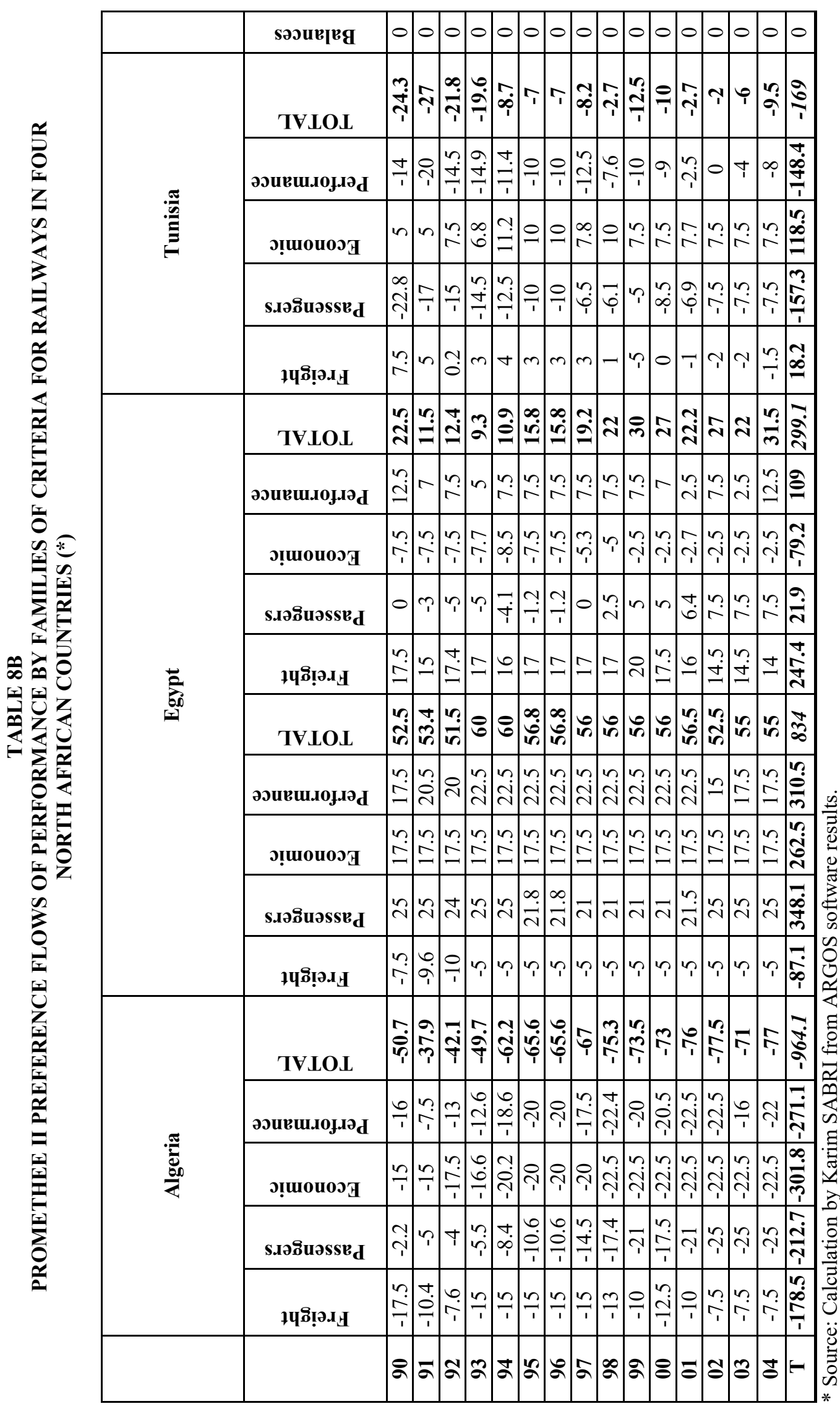




\section{Interpretation of the Results of the Multi-Period and Multi-Criteria Rankings}

According to Table 6, we achieved three levels of analysis of the performances of railway sectors in North Africa for every year 1990-2004.

At the upper level, we obtained Table 8a, which is the aggregation of preference flows of Table 8b, i.e., the four applications of Promethee II, to the data of Table 7 for each family of criteria, taking into account the ventilation and the thresholds of Table 6 .

Each cell of Table $8 \mathrm{~b}$ contains a multi-criteria net preference flow indicating how much the corresponding country sector dominates the other ones in this family, if it is positive. A negative flow indicates how much the sector is dominated by the others in its family.

For instance, in 1990 and 2004, the Egyptian sector alone dominates the three other sectors on the criterion passengers; it also dominates them on the criterion performance and economic. But we notice that the Morocco sector dominates in freight for all years.

The horizontal total additions yield to zero because those of the dominated ones exactly compensate the flows of the dominating sectors.

The general rankings according to each of these two dimensions and together are, therefore:

Technical performances (TP): Morocco $1^{\text {st }}(269.3)$, Egypt $2^{\text {nd }}(261)$, Tunisia $3^{\text {rd }}(-139.1)$, Algeria $4^{\text {th }}(-391.2)$.

Economic performances (EP): Egypt $1^{\text {st }}(573)$, Morocco $2^{\text {nd }}(29.8)$, Tunisia $3^{\text {rd }}(-29.9)$, Algeria $4^{\text {th }}(-572.9)$.

Together: Egypt $1^{\text {st }}(834)$, Morocco $2^{\text {nd }}(299.1)$, Tunisia $3^{\text {rd }}(-169)$, Algeria $4^{\text {th }}(-964.1)$

Table 9 summarizes the networks' rankings according to the three considered dimensions.

TABLE 9

RANKINGS OF FOUR NETWORKS BY TECHNICAL (TP) AND ECONOMIC (EP) PERFORMANCES AND TOGETHER

\begin{tabular}{|c|c|c|c|c|c|c|c|c|}
\hline & \multicolumn{2}{|c|}{ Algeria } & \multicolumn{2}{|c|}{ Egypt } & \multicolumn{2}{|c|}{ Morocco } & \multicolumn{2}{|c|}{ Tunisia } \\
\hline Function & TP & EP & $\mathrm{TP}$ & EP & TP & EP & TP & EP \\
\hline Ranking & 4th & 4th & 2nd & $1 \mathrm{st}$ & $1 \mathrm{st}$ & 2nd & $3 \mathrm{rd}$ & $3 \mathrm{rd}$ \\
\hline General Ranking & \multicolumn{2}{|c|}{ 4th } & \multicolumn{2}{|c|}{$1 \mathrm{st}$} & \multicolumn{2}{|c|}{ 2nd } & \multicolumn{2}{|c|}{$3 \mathrm{rd}$} \\
\hline
\end{tabular}

TABLE 10

RANKINGS OF THE FOUR NETWORKS ACCORDING TO THE SIZE, THE MALMQUIST INDEX, AND TO THE PROMETHEE II METHOD

\begin{tabular}{c|c|c|c|c}
\hline Ranks & $1^{\text {st }}$ & $2^{\text {nd }}$ & $3^{\text {rd }}$ & $4^{\text {th }}$ \\
\hline Size ranking & Egypt & Algeria & Tunisia & Morocco \\
\hline Malmquist index ranking & Tunisia & Morocco & Egypt & Algeria \\
\hline Promethee II ranking & Egypt & Morocco & Tunisia & Algeria \\
\hline
\end{tabular}

Finally, we observe that the Egyptian railway sector is the sector having a positive preference flow for the two dimensions for all the period. We recall, however, and confirm that the size of the network cannot provide a good evaluation of the company's performance even if the Egyptian network remains at the first position according to Promethee ranking, but not for the productivity comparison.

\section{CONCLUSION}

We notice that the positions of Morocco (2nd) and Algeria (4th) are the same according to the two methods of multidimensional analysis, whereas Tunisia is at the top according to the Malmquist index and Egypt takes the head in Promethee II. Similar to another study made about telecom performances by Colson et al., we could conclude here using their own words: 
"Anyway, the two methods of analysis are indeed different in scope and used data and they give complementary information. While the Malmquist index analysis can separate the effects of technological and management changes, the 3-levels multiple criteria method can score the preference flows via two levels of aggregation and highlights the two dimensions of service and enterprise performance, useful to fully evaluate a utility sector ...."

In general, we can confirm that all the networks analyzed in this paper, much like with the majority of the public companies in the developing countries, need to apply much more effort in order to improve their performance, mainly in management. For J. Nellis, many African state-owned enterprises (SOEs), particularly those working in infrastructure, have a long history of poor performance. The reasons for the heavy African reliance on SOEs and their unsatisfactory performance are several. The failure of the African States in this respect has given rise to a reform approach that relies much more heavily on private sector participation and ownership (Nellis).

\section{ACKNOWLEDGEMENT}

Translated \& edited by American Publishing Services (https://americanpublishingservices.com/).

\section{ENDNOTES}

1. Let us recall that indexes are f.i. for the last line 0.988 and 1.044, producing by multiplication: 1.032 ; thus, $3.2 \%$ of growth decomposed into $-1.2 \%$ and $4.4 \%$. The figures of the last column can be obtained sometimes by an addition as an approximation.

2. The Promethee method we use is a simplification of the general method exposed by Brans et al.

\section{REFERENCES}

Brans, J.P., Vincke, P., \& Mareschal, B. (1986). How to Select and to Rank Projects: The Promethee Method. Eur. J. Oper. Res., 24(2), 228-238.

Coelli, T., \& Perelman, S. (1999). A Comparison of Parametric and Non-parametric Distance Functions: With Application to European Railways. Eur. J. Oper. Res., 117(2), 326-339.

Coelli, T., Estache, A., Perelman, S., \& Trujillo, L. (2003). A primer on Efficiency Measurement for Utilities and Transport Regulators. Washington: World Bank Institute Studies.

Colson, G. (2000). The OR's Prize Winner and the Software ARGOS: How a Multi-judge and Multicriteria Ranking GDSS Helps a Jury to Attribute a Scientific Award. Comp. \& Oper. Res., 27, $741-755$.

Colson, G., \& Mbangala, A.M. (1998). Evaluation multicritère d'entreprises publics du rail. Fineco, 8(1), $45-72$.

Colson, G., Sabri, K., \& Mbangala, A.M. (2006). Multiple Criteria and Multiple Periods Performance Analysis: The Comparison of Telecommunications Sectors in the Maghreb Countries. J Telecom. \& Info. Techno., 4, 67-80.

Estache, A., \& Kouassi, E. (2002, September). Sector Organization, Governance and the Inefficiency of African Water Utilities. World Bank Pol. Res., Working Paper 2890.

Estache, A., Perelman, S., \& Trujillo, L. (2005, February). Infrastructure Performance and Reform in Developing and Transition Economies: Evidence from a Survey of Productivity Measures. World Bank Pol. Res., Working Paper 3514.

Estache, A., Perelman, S., \& Trujillo, L. (2007). Measuring Quantity-Quality Trade-offs in Regulation: The Brazilian Freight Railways Case. Annals of Public and Cooperative Economics, 78(1), 1-20.

Färe, R., Grosskopf, S., Lindgren, B., \& Roos, P. (1992). Productivity changes in Swedish Pharmacies 1980-1989: A Non-parametric Malmquist Approach. J. Product. Anal., 3, 85-101. 
Färe, R., Grosskopf, S., Norris, M., \& Zhang, Z. (1994). Productivity Growth, Technical Progress and Efficiency Change in Industrialized Countries. The American Economic Review, 84, 66-83.

Mbangala, A.M. (2004). Management of Railways in Sub-Saharan Africa: Productivity Analysis. Rail International, 12(2), 13-21.

Nellis, J. (1988). The Institutional Framework: Organization, Management and Supervision of Tanzanian Parastatals. Unpublished chapter in World Bank report on Tanzanian public enterprises.

Nellis, J. (2005). The Evolution of Enterprise Reform in Africa: From State-owned Enterprises to Private Participation in Infrastructure - and Back? Centre for Global Development, Washington.

Plane, P. (1999). Privatisation, Technical Efficiency and Welfare Consequences: The Case of the Côte d'Ivoire Electricity Company (CIE). World Development, 27(2), 343-360.

38 Journal of Strategic Innovation and Sustainability Vol. 16(4) 2021 